\title{
KEDUDUKAN DAN JUMLAH MAHAR DI NEGARA MUSLIM
}

\author{
Qodariah Barkah \\ IAIN Raden Fatah Palembang \\ Jl. Prof. K.H. Zainal Abidin Fikri, Palembang, Sumatera Selatan \\ E-mail: qodariah70@gmail.com
}

\begin{abstract}
The Position and Number of Dowries in Muslim Countries. The dowry has a significant role in a marriage. The obligation of the husband to provide a dowry for wife has led to various interpretations by mufassir and jurists. The Qur'an uses the term dowry gift accompanied with the words ma'ruff. Currently, various Muslim countries that have undertaken family law reform have included a dowry as one of the objects of the problem that must be given rules in detail, so that if in future there is a problem in the household and has been linked with the dowry then the matter can be settled by a judge.
\end{abstract}

Keywords: dowry, marriage, Muslim countries, family law

\begin{abstract}
Abstrak. Kedudukan dan Jumlah Mahar di Negara Muslim. Mahar mempunyai peranan yang signifikan dalam suatu perkawinan. Kewajiban suami untuk memberikan mahar kepada isteri mengakibatkan adanya pelbagai interprestasi dari para mufasir dan fukaha. Alquran menggunakan istilah pemberian mahar diiringi dengan kata-kata márûf. Saat ini, pelbagai negara Muslim yang melakukan reformasi dalam hukum keluarga telah memasukkan mahar sebagai salah satu obyek masalah yang harus diberikan aturan secara rinci, sehingga apabila di kemudian terjadi problem dalam rumah tangga dan memiliki keterkaitan dengan mahar maka hal ini dapat diselesaikan oleh hakim.
\end{abstract}

Kata Kunci: mahar, perkawinan, negara Muslim, hukum keluarga

\section{Pendahuluan}

Reformasi bidang hukum keluarga di pelbagai negara Muslim telah dimulai sejak awal abad ke-20. Di antara reformasi hukum keluarga yang paling banyak dilakukan adalah reformasi dalam bidang hukum perkawinan. Isu tentang mahar merupakan salah satu dari beberapa isu pembaharuan yang dilakukan dalam hukum perkawinan. ${ }^{1}$ Beberapa negara Muslim, seperti Maroko, Yordania, Pakistan, Bangladesh, Mesir, Syria, Malaysia, dan Indonesia telah mengatur masalah mahar secara rinci dan khusus dalam beberapa pasal dari undang-undang hukum keluarga yang diberlakukan di negara tersebut.

Menurut ketentuan yang terdapat dalam Alquran ${ }^{2}$ dan $\mathrm{Hadis}^{3}$, para ulama sepakat bahwa pemberian mahar merupakan sesuatu yang wajib dan syarat

Naskah diterima: 15 Februari 2014, direvisi: 25 Maret 2014, disetujui untuk terbit: 10 Mei 2014.

${ }^{1}$ Khoiruddin Nasution, Islam tentang Relasi Suami dan Isteri (Hukum Perkawinan 1), (Jakarta: ACAdeMIA\&TAZZAFA, 2004), h. 123.

${ }^{2}$ Ada sejumlah ayat Alquran yang berbicara tentang mahar yaitu Q.s. al-Baqarah [2]: 236-237, al-Nisâ' [4]: 4, 24 dan 25, al-Mâidah [5]: 5, dan al-Mumtahanah [60]:10.

${ }^{3}$ Lihat Hadis tentang mahar dalam Imâm al-Bukhârî, Shahîh alBukhârî, (Beirut: Dâr al-Fikr, 1978). sah perkawinan ${ }^{4}$, tetapi bukan rukun perkawinan, karena mahar tidak harus ada pada saat ijab-kabul berlangsung.

Kewajiban pemberian mahar dari suami kepada isteri melahirkan pelbagai interpretasi dari mufassir dan fukaha, karena sejumlah nas tentang mahar, baik Alquran maupun Hadis, memiliki variasi teks yang berbeda sehingga menimbulkan perbedaan dalam memahami nas yang ada. Di antaranya mengenai jumlah maksimal dan minimal mahar serta status mahar ${ }^{5}$.

Pemberian mahar dalam perkawinan tidak dapat dipisahkan dari tradisi perkawinan pinang dalam masyarakat Arab pra-Islam. Pada masa itu, seorang laki-laki yang ingin meminang seorang perempuan harus melalui seorang laki-laki yang menjadi wali atau anak perempuannya sendiri, dan laki-laki yang bersangkutan memberikan mahar kepada wali, kemudian menikahinya. ${ }^{6}$ Kenyataan ini berimplikasi pada status kepemilikan mahar yang dianggap sebagai

\footnotetext{
${ }^{4}$ Amiur Nuruddin dan Azhari Akmal Tarigan, Hukum Perdata Islam di Indonesia,(Jakarta: Raja Grafindo Persada, 2004), h.84.

${ }^{5}$ Khoiruddin Nasution, Islam tentang Relasi Suami dan Isteri (Hukum Perkawinan 1), h. 126.

${ }^{6}$ Sayyid Sâbiq, Fiqh al-Sunnah, (Beirut: Dâr al-Kitâb al-Arabî, 1392 H/1973M), Jilid 2, h. 8.
} 
milik wali, bukan milik isteri (perempuan yang akan dinikahi).

Kaitannya dengan jumlah mahar, Alquran menggunakan istilah yang sangat fleksibel, yaitu ma'rûf. Kata ma'rûf dapat diartikan "sepantasnya", "sewajarnya" atau "semampunya". Dalam hadisnya, Nabi Muhammad Saw. juga menyebutkan nilai mahar dengan jumlah yang terkadang sangat murah dan terkadang kedengarannya cukup mahal ${ }^{8}$. Maka dalam hal ini harus dapat dipahami secara jelas dan bijaksana sehingga masalah mahar tidak akan menghalangi terlaksananya perkawinan.

Pada masa sekarang ini, pelbagai negara Muslim yang melakukan reformasi dalam hukum keluarga telah memasukkan mahar sebagai salah satu obyek masalah yang harus diberikan aturan secara rinci, sehingga apabila di kemudian terjadi problema dalam rumah tangga dan memiliki keterkaitan dengan mahar maka hal ini dapat diselesaikan oleh hakim.

Artikel ini akan membahas tentang reformasi hukum keluarga Muslim yang mengatur masalah mahar di pelbagai negara yaitu Maroko, Yordania, Syria, Pakistan, dan Indonesia. Pembahasannya meliputi keberanjakan dari kitab fikih dan analisis perbandingan yang meliputi perbandingan vertikal dan horizontal antara pelbagai negara tersebut.

\section{Substansi Fikih}

Menurut al-Syîrâzî, salah seorang ulama Mazhab alSyâfi'̂̀, dengan tegas menyebutkan bahwa akad nikah sebagai 'aqd mu'âwadhah yang dipahami sebagai akad tukar menukar antara suami isteri. ${ }^{9}$ Karena itu, dengan akad nikah suami dan isteri berhak melakukan tukar menukar dan bukan dalam pengertian berhak untuk memiliki. Sehingga pemahaman yang diambil adalah suami yang telah memberikan mahar kepada isteri bukan berarti telah memiliki isterinya sebagaimana kepemilikannya terhadap suatu barang.

Adapun kadar mahar yang wajib berdasarkan Q.s. al-Nisâ'[4]: 20 adalah sesuatu yang mempunyai nilai atau berharga. Hanya saja disunatkan tidak melebihi dari mahar yang pernah diberikan suami kepada isteri-isterinya dan mahar anak perempuannya, yakni maksimal 500 dirham $^{10}$. Mahar dapat juga hanya

\footnotetext{
${ }^{7}$ Q.s. al-Nisâ [4]: 25.

${ }^{8}$ Hadits yang diriwayatkan Muslim menyebutkan bahwa jumlah mahar yang diberikan Nabi Muhammad Saw. kepada isteri-isterinya adalah 12 awqiyyah atau sama dengan 500 dirham.

${ }^{9}$ Abû Ishâq Ibrâhîm al-Syîrâzî, Al-Muhadzdzab fî Fiqh al-Imâm al-Syâfî̀, (Semarang: Thoha Putra,t.t.), Jilid II, h. 33.

${ }^{10}$ Muhammad ibn Idrîs al-Syâfi'î, Al-Umm, (Beirut: Dâr al-Fikr,
}

sepotong besi, bahkan dapat juga berupa upah (jasa). ${ }^{11}$

Menurut pendapat Ibn Qudâmah dari Mazhab Hanbalî, kewajiban pertama dari suami terhadap isteri adalah pemberian mahar. Menurutnya, mahar dengan kadar kepantasan merupakan sesuatu yang wajib dalam perkawinan, tetapi tidak harus ada ketika pelaksanaan akad. Kewajiban suami membayar mahar kalau suami sudah menyentuh isterinya. Sebaliknya, suami belum wajib membayar kalau belum menyentuh isterinya. Dasar hukum mengenai hal itu adalah Hadis Nabi yang menyuruh suami membayar mahar kepada isterinya kalau sudah menyentuh. Dengan demikian, kewajiban membayar mahar bukan pada waktu akad, tetapi setelah terjadi sentuhan/hubungan suami istri (wath).$^{12}$

Perceraian yang terjadi karena fasakh dan terjadi sebelum menyentuh/dukhôl tidak mengakibatkan wajibnya suami membayar mahar. Namun apabila terjadi perceraian karena talak dan sebelum dukhûl, maka mahar wajib dibayar setengah. ${ }^{13}$ Disamping itu, ditegaskan juga oleh Ibn Qudâmah bahwa isteri berhak menolak hubungan dengan suami dengan alasan karena suami belum membayar mahar. ${ }^{14}$

Dalam Kitab al-Muwaththa', Imâm Mâlik menuliskan beberapa Hadis yang berhubungan dengan mahar, di antaranya adalah tentang seorang laki-laki yang menikahi seorang perempuan dan telah menyentuhnya, meskipun perempuan tersebut mengidap penyakit, maka pembayaran mahar harus dilakukan kepada perempuan tersebut. Selain itu, Imâm Mâlik berpendapat bahwa kalau terjadi perceraian sebelum suami menyentuh isterinya, dan isterinya tersebut masih berstatus gadis, maka ia berhak mendapat setengah dari mahar yang diperjanjikan. Pandangan ini, menurut Imâm Mâlik, sejalan dengan ketentuan dalam Q.s. al-Baqarah [2]: 237 ditambah dengan sejumlah riwayat yang secara prinsip menegaskan bahwa kalau suami sudah menyentuh isterinya menjadikannya wajib membayar mahar. ${ }^{15}$

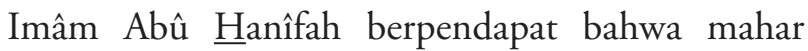
adalah kewajiban tambahan dalam akad nikah dan statusnya sama dengan nafkah. Namun mahar tidak harus ada pada saat akad nikah dengan pengertian

$\overline{\text { 2002), Jilid V, h. } 143}$

${ }^{11}$ Muhammad ibn Idrîs al-Syâfî̀, Al-Umm, h. 144-145.

${ }^{12}$ Muwaffaq al-Dîn Abû Muhammad 'Abd Allâh ibn Ahmad ibn Qudâmah, Al-Mughnî wa al-Syarh al-Kabîr, (Beirut: Dâr al-Fikr, 1984 M), Jilid VII, h. 344.

${ }^{13}$ Muwaffaq al-Dîn Abû Muhammad 'Abd Allâh ibn Aḥmad ibn Qudâmah, Al-Mughnî wa al-Syarh al-Kabîr, h. 422-425.

${ }^{14}$ Muwaffaq al-Dîn Abû Muhanammad 'Abd Allâh ibn Aḥmad ibn Qudâmah, Al-Mughnî wa al-Syarh al-Kabîr, h. 286.

${ }_{15}$ Mâlik ibn Anas, Al-Muwaththa', di-tash $\underline{h} \underline{\underline{h}} \underline{\text { oleh Muhammad }}$ Fưâd 'Abd al-Bâqî, (Beirut: Dâr al-Fikr, 1985), h. 236. 
bahwa tanpa mahar, akad nikah adalah sah. Dasar hukum kewajiban membayar mahar adalah berdasarkan Q.s. al-Nisầ [4]: $24 .^{16}$

\section{Ketentuan Mahar di Beberapa Negara}

\section{Maroko (Mewakili Negara Wilayah Afrika Utara)}

Di Maroko, undang-undang yang mengatur tentang hukum keluarga yaitu Moroccan Code of Personal Status 195 dimana secara khusus mengatur mahar dalam bab tersendiri, yaitu bab ke-4, pasal 16-24. ${ }^{17}$ Pembahasan diawali dengan defenisi apa yang dapat menjadi mahar dan ketentuan umum tentang mahar. Tentang defenisi mahar disebutkan bahwa mahar adalah uang yang diberikan oleh suami untuk menunjukkan keinginannya melaksanakan akad nikah untuk membangun keluarga dan memperkuat landasan kasih sayang antara suami dan isteri. ${ }^{18}$ Adapun yang dapat menjadi mahar adalah segala sesuatu yang sah menjadi obyek akad ${ }^{19}$ dan tidak ada batasan minimal dan maksimal mahar. ${ }^{20}$ Kemudian disebutkan bahwa mahar boleh dibayar kontan atau hutang, seluruhnya atau sebagian, pada waktu akad nikah. ${ }^{21}$ Keharusan membayar mahar seluruhnya atau sebagian adalah setelah terjadi hubungan badan. ${ }^{22}$ Isteri berhak mendapat mahar penuh karena 2 (dua) alasan, yaitu karena kematian atau karena sudah melakukan hubungan suami isteri (ba'd dukhûl). ${ }^{23}$

Undang-undang tersebut juga mengatur tentang status kepemilikan mahar. Menurutnya, mahar merupakan kekayaan mutlak isteri dan dia berhak serta berkuasa untuk menggunakannya sesuai dengan keinginannya. Suami tidak berhak meminta mahar untuk kepentingan alat-alat rumah tangga, perabot rumah tangga, atau pakaian. ${ }^{24}$ Selanjutnya dijelaskan pula bahwa wali, baik bapak atau siapa saja, dilarang menerima sesuatu untuk dirinya yang berkaitan dengan perkawinan anak perempuannya atau siapa saja yang menjadikannya sebagai wali. ${ }^{25}$

Dalam masalah penuntutan mahar yang terhutang,

${ }^{16}$ Syams al-Dîn al-Sarakhsî, Al-Mabsûth, (Beirut: Dâr al-Mảrifah, 1989 M), Jilid V, h. 62.

17 Tahir Mahmood, Family Law Reform in The Muslim World, (Bombay: N.M Tripathi PVT, 1970), h.122. Bandingkan dengan Dawoud El Alami dan Doreen Hinchcliffe, Islamic Marriage and Divorce Laws, (London: Kluwer Law International, 1996), h. 200201.

${ }^{18}$ Pasal 16

${ }^{19}$ Pasal 17a.

${ }^{20}$ Pasal 17 b.

${ }^{21}$ Pasal 20 ayat (1).

${ }^{22}$ Pasal 20 ayat (2).

${ }^{23}$ Pasal 20 ayat (3).

${ }^{24}$ Pasal 18.

${ }^{25}$ Pasal 19. maka isteri berhak menuntut pembayaran mahar sebagai hutang suami apabila isteri telah menyerahkan dirinya dan ketidakmampuan suami membayar mahar tidak dapat dijadikan sebagai alasan perceraian. ${ }^{26}$ Isteri berhak menerima setengah mahar apabila suami menceraikannya sebelum melakukan hubungan suami isteri ( $q a b l$ dukhîl). Tetapi kalau alasan perceraian karena isteri cacat, maka isteri tidak berhak atas mahar. Jika isteri mengajukan perceraian dengan alasan suami cacat dan telah terjadi hubungan suami isteri, maka isteri berhak mendapatkan mahar seluruhnya. ${ }^{27}$

Adapun mengenai kewenangan wali dalam masalah penentuan mahar, maka dalam peraturan tersebut dijelaskan bahwa seorang perempuan yang sudah dewasa dan akan menikah dengan jumlah mahar yang kurang dari mahar mitsil, maka dalam hal ini wali tidak boleh memaksa perempuan tersebut untuk menikah. ${ }^{28}$ Jika terjadi perbedaan pendapat antara suami dan isteri tentang apakah mahar sudah dibayar atau belum, maka dalam hal ini diatur bahwa pendapat isteri yang diterima kalau sebelum terjadi hubungan suami isteri. Sebaliknya, apabila sudah terjadi hubungan suami isteri maka pendapat suami yang diterima. ${ }^{29}$

\section{Yordania: Mewakili Negara Wilayah Asia Barat}

Dalam Undang-Undang Yordania No.61 tahun 1976, masalah mahar dibahas dalam pembahasan tersendiri, yaitu pada bagian ke-8 yang memuat 21 pasal, pasal $44-65 .{ }^{30} \mathrm{Dalam}$ pasal ini pembahasan tentang mahar dilakukan secara rinci. Namun sebelum itu, masalah mahar juga disinggung pada bagian aturan-aturan yang berhubungan dengan perkawinan dan di dalamnya memuat masalah mahar, nafkah, dan hak untuk saling mewarisi. Di sana dijelaskan tentang status mahar, yaitu kalau akad nikah sudah dilakukan, mahar dan nafkah menjadi wajib dan juga ada hak untuk saling mewarisi. ${ }^{31}$

Kemudian disebutkan akibat dari mahar, bahwa setelah menerima mahar, isteri wajib menunjukkan sifat patuh kepada suami, tinggal di rumah suami, dan pindah bersama suami ke tempat yang diinginkan suami, meskipun di luar negeri, dengan syarat tempat tinggal tersebut aman. Kalau isteri menolak (tidak patuh) maka hak nafkah hilang. ${ }^{32}$

${ }^{26}$ Pasal 21.

${ }^{27}$ Pasal 22.

${ }^{28}$ Pasal 23.

${ }^{29}$ Pasal 24.

${ }^{30}$ Dawoud El Alami dan Doreen Hinchcliffe, Islamic Marriage and Divorce Laws, h. 90-94.

${ }^{31}$ Pasal 35.

${ }^{32}$ Pasal 37. 
Adapun jenis mahar terdiri atas: (1) Mahar khusus, yaitu mahar yang disetujui kedua pihak pada waktu akad nikah. (2) Mahar sepantasnya (mahar mitsil), yaitu mahar yang sesuai dengan status sosial keluarga isteri. Jika sulit untuk menetapkan mahar yang sesuai maka disesuaikan dengan kepantasan di tempat tinggalnya. ${ }^{33}$ Mahar khusus boleh dibayar tunai atau hutang, seluruhnya atau sebagian, dan dibuktikan dengan dokumen tertulis. Kalau tidak ada penjelasan tentang waktu pembayaran berarti mahar dibayar tunai. ${ }^{34}$ Pembatalan membayar mahar adalah karena suami wafat. ${ }^{35}$

Akibat-akibat dari mahar dapat digambarkan bahwa kalau isteri menerima sebagian mahar, kemudian setuju sisanya dibayarkan pada waktu tertentu, isteri tidak berhak menolak patuh pada suami. ${ }^{36}$ Kalau jumlah mahar sudah ditetapkan dalam akad nikah, maka harus dilunasi seluruhnya. Sementara kalau perceraian terjadi sebelum terjadi hubungan badan, maka wajib membayar setengah mahar. ${ }^{37}$ Kalau pisah terjadi sebelum terjadi hubungan badan antara suami dan isteri dan atas permintaan isteri karena ada cacat atau penyakit suami atau permintaan wali karena tidak se-kufu', maka mahar hilang seluruhnya. ${ }^{38}$ Demikian pula mahar kembali kepada suami kalau terjadi perceraian sebelum hubungan badan. ${ }^{39}$ Mahar setengah harus dibayar kalau perceraian terjadi atas inisiatif suami dan belum terjadi hubungan badan, misalnya karena perceraian, îlâ', li'ân, murtad, impoten, menolak Islam padahal isterinya Muslimah, atau tindakan-tindakan lain dari suami yang menyebabkan putusnya perkawinan. ${ }^{40}$

Demikian pula hak mahar hilang seluruhnya kalau terjadi perceraian karena ulah dan tindakan isteri, misalnya isteri murtad, menolak Islam padahal suaminya Muslim dan isteri bukan ahli kitab, atau tindakan-tindakan lain yang mengakibatkan putusnya perkawinan. Jika menerima sesuatu sebagai mahar, isteri harus mengembalikannya. ${ }^{41}$ Juga hak isteri mendapat mahar hilang seluruhnya kalau perceraian terjadi atas inisiatif suami dengan alasan ada cacat atau penyakit isteri dan perceraian terjadi sebelum hubungan badan. Demikian juga suami berhak minta kembali kalau sudah memberikan mahar. ${ }^{42}$ Mahar mitsl wajib dibayar

\footnotetext{
33 Pasal 44.

${ }^{34}$ Pasal 45.

35 Pasal 46.

36 Pasal 47.

37 Pasal 48.

38 Pasal 49.

${ }^{39}$ Pasal 50.

${ }^{40}$ Pasal 51.

${ }^{41}$ Pasal 52.

${ }^{42}$ Pasal 53.
}

kalau tidak ada mahar khusus dalam akad nikah atau karena tidak ada mahar dalam perkawinan. ${ }^{43}$

Kalau terjadi perbedaan pendapat tentang jumlah mahar khusus dan tidak ada bukti tentang itu, maka mahar mitslmenjadi wajib. Tetapi kalau tuntutan datang dari isteri dan jumlahnya tidak lebih besar dari mahar mitsl, maka wajib dibayar. Kalau tuntutan datang dari suami wajib dibayar kalau jumlahnya tidak lebih dari mahar mithl. ${ }^{44}$

Demikian pula kalau terjadi perbedaan pendapat antara suami dan isteri tentang jumlah mahar khusus, maka kewajiban isteri untuk membuktikan. Dan kalau tidak dapat membuktikan, maka pendapat suami yang diterima dengan sumpah, kecuali suami menentukan mahar yang tidak sejalan dengan adat, maka mahar mitsl yang dibayar. Pada akhirnya tidak ada tuntutan yang dapat dikabulkan tentang mahar yang bertentangan dengan akad nikah, kecuali didukung dengan bukti. ${ }^{45}$

Adapun status kepemilikannya, mahar menjadi kekayaan isteri. ${ }^{46}$ Tidak ada pihak yang berhak meminta sesuatu dari suami, baik bapak sendiri atau keluarga, yang berkaitan dengan penerimaan isteri dalam perkawinan. Bahkan suami berhak menuntut kembali kalau ada sesuatu yang diberikan yang berkaitan dengan perkawinan. ${ }^{47}$ Tetapi disebutkan pula, jika yang bertindak sebagai wali adalah bapak atau kakek, maka dia berhak memiliki mahar anak/cucunya, bahkan meskipun si anak sudah mempunyai hak penuh, dengan syarat suami tidak menolak membayar. ${ }^{48}$ Jadi terkesan bagian dari mahar tersebut boleh diambil wali. Kemudian disebutkan, suami boleh menaikkan jumlah mahar setelah akad nikah atau menurunkannya oleh isteri, dengan syarat diterima oleh para pihak yang bersangkutan. ${ }^{49}$

\section{Syria: Mewakili Negara Wilayah Asia Barat}

Dalam Undang-Undang Syria No.34 tahun 1975, masalah mahar menjadi sub pembahasan sendiri, bagian ke-1 dari bab ke-4, dengan judul "Akibat-Akibat Perkawinan", pasal 53-64. ${ }^{50}$ Dalam undang-undang tersebut dijelaskan tentang status mahar, bahwa mahar wajib diberikan oleh suami berdasarkan akad yang sah, baik disebutkan secara khusus pada waktu akad nikah
${ }^{43}$ Pasal 54.
${ }^{44}$ Pasal 57.
${ }^{45}$ Pasal 58.
${ }^{46}$ Pasal 61.
${ }^{47}$ Pasal 62.
${ }^{48}$ Pasal 64.
${ }^{49}$ Pasal 63.
${ }^{50}$ Dawoud El Alami dan Doreen Hinchcliffe, Islamic Marriage and Divorce Laws, h. 224-226. 
atau tidak. ${ }^{51}$ Demikian juga dalam undang-undang tersebut ditetapkan tidak ada jumlah minimal dan maksimal mahar. ${ }^{52}$

Adapun yang dapat menjadi mahar adalah apa saja yang sah diperjualbelikan. ${ }^{53}$ Demikian juga ditetapkan bahwa mahar harus menjadi hutang prioritas, sama dengan nafkah. Hal ini sejalan dengan isi pasal 1120 Kitab Perdata (Perdata Syria). ${ }^{54}$

Kalau ada pihak yang menyatakan bahwa ada persetujuan yang bersifat rahasia tentang mahar, seharusnya dibuktikan dengan cara yang semestinya. Dari hasil pembuktian tersebut hakim harus menetapkan adanya mahar mitsl kalau tidak ada mahar khusus. ${ }^{55}$ Demikian pula kalau ada hutang yang berkaitan dengan masalah perkawinan dan perceraian harus dalam dokumen tertulis. Hal ini sejalan dengan isi paragraf 1 pasal 468 tentang Prinsip-Prinsip Beracara Undang-Undang No. 84 tahun $1952 .{ }^{56}$

Kaitannya dengan pembayaran, mahar dapat dibayar kontan atau hutang, seluruhnya atau sebagian. Dalam kasus tidak ada ketentuan tentang hal tersebut, berlaku hukum adat. ${ }^{57}$ Penangguhan mahar kalau tidak ditetapkan dalam akad nikah, maksimal sampai terjadi perceraian atau meninggal. ${ }^{58}$ Naik atau turunnya jumlah mahar tidak dapat diterima kalau dilakukan dalam masa perkawinan atau masa iddah dalam kasus terjadi perceraian. Perubahan tidak dapat terjadi kecuali ada keputusan hakim. Kalau terjadi demikian di luar penetapan pengadilan harus dikembalikan pada akad nikah asli/semula. ${ }^{59}$

Kemudian dijelaskan akibat-akibat hukum dari tindakan tertentu yang berkaitan dengan mahar, bahwa kalau jumlah mahar sudah ditetapkan pada akad, kemudian terjadi perceraian sebelum hubungan badan atau mengundurkan diri secara sah, maka mahar harus dibayar setengah. ${ }^{60}$ Kalau perceraian terjadi atas permintaan isteri sebelum hubungan badan maka mahar tidak harus dibayar. ${ }^{61}$

Adapun status kepemilikannya, bahwa isteri mempunyai hak penuh atas mahar yang diterimannya, dan suami harus menjadikannya sebagai hak mutlak

\footnotetext{
51 Pasal 53.

52 Pasal 54, ayat 1.

53 Pasal 54, ayat 2.

${ }^{54}$ Pasal 54, ayat 3.

55 Pasal 54, ayat 4.

56 Pasal 54, ayat 5.

57 Pasal 55.

58 Pasal 56.

59 Pasal 57.

${ }^{60}$ Pasal 58.

61 Pasal 59.
}

isteri kalau isteri memenuhi syarat sebagai subyek hukum (mukalaf), kecuali isteri memberikan kekuasaan kepada suami pada waktu akad nikah. ${ }^{62}$

Peraturan antar waktu seharusnya tidak diterapkan dalam kasus mahar yang dibayar dengan kontan, meskipun dalam perjanjiannya ditetapkan demikian, selama perkawinan masih bertahan. ${ }^{63}$ Dalam kasus mahar khusus tidak ditetapkan, maka mahar mitsl harus dibayarkan segera setelah selesai akad nikah. ${ }^{64}$

Sementara jika hubungan badan sudah terjadi dari satu perkawinan yang tidak sah, sementara jumlah mahar belum ditentukan, wanita tersebut berhak mendapatkan mahar yang pantas. Tetapi kalau jumlah mahar sudah ditentukan, maka dibayar mahar yang lebih kecil antara mahar mitsl dan mahar khusus. ${ }^{65}$ Kalau suami meninggal karena sakit, sementara mahar khusus lebih besar dari mahar mitsl, maka aturan waris yang diterapkan untuk menyelesaikan sisanya. ${ }^{66}$

\section{Pakistan: Mewakili Negara Wilayah Asia Selatan}

Menurut undang-undang yang berlaku di negara Pakistan, dalam pasal 3 dinyatakan bahwa jumlah maksimal mahar adalah 5000 rupee. Selanjutnya, dalam pasal 4 dijelaskan bahwa hadiah/kado yang boleh diberikan tidak lebih dari 1000 rupee, dan para pejabat negara tidak boleh menerima hadiah/kado untuk perkawinannya atau perkawinan anaknya (laki-laki atau perempuan), yang pemberiannya berhubungan dengan jabatannya. Pasal 5 menyebutkan bahwa semua hak yang diberikan sebagai mahar, pemberian yang berhubungan dengan perkawinan, atau hadiah (kado) yang diberikan menjadi hak mutlak isteri, dan untuk kepentingannya tidak boleh dibatasi dengan sesuatu apapun. Pasal 6 menyebutkan bahwa kebutuhan-kebutuhan yang berhubungan dengan perkawinan, seperti untuk upacara walimah dan semacamnya, tidak boleh lebih dari 2500 rupee. Adapun pasal 8 menyebutkan bahwa bapak atau yang mewakilinya, dalam waktu 15 hari setelah akad nikah harus melaporkan kepada pegawai pencatat tentang jumlah yang dihabiskan untuk perkawinan yang bersangkutan. Dan pasal 9 menetapkan bahwa seseorang yang melanggar aturan yang ada dalam undang-undang ini dapat dihukum dengan hukuman penjara maksimal 6 bulan. ${ }^{67}$

\footnotetext{
62 Pasal 60 ayat 1 .

${ }^{63}$ Pasal 60 ayat 2.

${ }^{64}$ Pasal 61 ayat 1.

65 Pasal 63.

66 Pasal 64

${ }^{67}$ Tahir Mahmood, Family Law Reform in The Muslim World, h.249-251.
} 


\section{Indonesia: Mewakili Negara Wilayah Asia Tenggara}

Dalam perundang-undangan Indonesia, masalah mahar diatur dalam Kompilasi Hukum Islam (KHI), yaitu pada bab ke-5 tentang mahar, yaitu pasal 30-38. Masalah mahar juga disinggung dalam bab ke-1 dalam ketentuan umum, pasal 1d. Isi dari pasal ini adalah definisi mahar. ${ }^{68}$ Ketika pembahasan rukun nikah pada bab ke-4 tentang rukun dan syarat perkawinan ditegaskan bahwa mahar tidak menjadi rukun nikah/ perkawinan. ${ }^{69}$ Kemudian ditetapkan asas mahar adalah sederhana dan mudah. ${ }^{70}$ Selanjutnya ditegaskan pula kepemilikan mahar adalah menjadi hak milik isteri. ${ }^{71}$ Adapun penyerahan pada prinsipnya adalah tunai, tetapi ada kemungkinan ditangguhkan. Demikian juga boleh lunas seluruhnya atau sebagian. ${ }^{72}$ Kemudian ditegaskan bahwa mahar bukan rukun nikah. ${ }^{73}$

Penjelasan selanjutnya adalah akibat talak. Suami yang mentalak isterinya sebelum hubungan badan wajib membayar setengah mahar yang telah ditentukan. Dalam kasus suami meninggal dunia sebelum hubungan badan, mahar yang diberikan menjadi hak penuh isteri. Sementara kalau perceraian terjadi sebelum hubungan badan dan jumlah mahar belum ditentukan, maka wajib membayar mahar mitsl. ${ }^{74}$

Dalam kasus mahar hilang sebelum diserahkan, wajib diganti. ${ }^{75}$ Kalau terjadi perbedaan pendapat tentang jenis dan nilai mahar, diselesaikan oleh hakim di pengadilan. ${ }^{76}$ Dalam kasus mahar mempunyai cacat tergantung sikap mempelai wanita. ${ }^{77}$

Dari pelbagai aturan tentang mahar yang masingmasing berlaku di 5 (lima) negara tersebut, maka terlihat bahwa dalam hukum keluarga, ketentuan mahar telah diatur secara rinci dengan mempertimbangkan pelbagai kemungkinan yang akan terjadi dalam suatu perkawinan di masa yang akan datang.

\section{Kondisi Sosio Historis}

Negara Maroko, antara tahun 1921-1956, berada dibawah dominasi politik Prancis dan Spanyol. Sistem hukum di kedua negara ini sedikit banyak mewarnai hukum lokal yang berlaku di Maroko. Hanya hukum

\footnotetext{
${ }^{68}$ KHI Pasal 1.

${ }^{69} \mathrm{KHI}$ pasal 34 ayat (10).

${ }^{70} \mathrm{KHI}$ pasal 31.

${ }^{71} \mathrm{KHI}$ pasal 32.

${ }^{72} \mathrm{KHI}$ pasa 33 ayat (1).

${ }^{73} \mathrm{KHI}$ pasal 34 ayat (1).

${ }^{74} \mathrm{KHI}$ pasal 35 ayat (1).

${ }^{75} \mathrm{KHI}$ pasal 36.

${ }^{76} \mathrm{KHI}$ pasal 37.

${ }^{77} \mathrm{KHI}$ pasal 38 ayat (1).
}

keluarga syariah, khususnya Mazhab Mâlikî, yang secara teguh tetap dianut. Namun demikian, dalam batas-batas tertentu terdapat beberapa elemen yang dipengaruhi hukum Prancis dan Spanyol serta kebiasaan-kebiasaan lokal. Aturan yang bercampur aduk ini terbungkus dalam hukum keluarga Maroko. Untuk menghindari kondisi tersebut, negara terpanggil melakukan kodifikasi hukum keluarga sekaligus melakukan reformasi atas dasar pertimbangan maslahat mursalah.

Tahun kemerdekaan Maroko (1956) kebetulan berbarengan dengan diundangkannya hukum keluarga di Tunisia, dan keadaan ini sangat mempengaruhi Maroko. Trend reformasi hukum keluarga di beberapa negara Islam mendorong Maroko ikut melakukan langkah yang sama. Interpretasi-interpretasi dan kebiasaan-kebiasaan yang menyimpang dari hukum Islam yang menghalangi kemajuan pembangunan dan peradaban harus disingkirkan. Oleh sebab itu, dipandang perlu adanya kodifikasi hukum keluarga. Pada 19 Agustus 1957 dibentuk sebuah komisi reformasi hukum berdasarkan keputusan kerajaan. Komisi bertugas menyusun rancangan undang-undang hukum perorangan dan kewarisan. Penyusunan rancangan undang-undang tersebut berdasarkan pada: ${ }^{78}$ (1) Beberapa prinsip dari mazhab-mazhab hukum fikih, khususnya Mazhab Mâlikî. (2) Doktrin maslahat mursalah. (3) Undang-undang yang berlaku di beberapa negara Muslim lainnya.

Rancangan tersebut kemudian resmi menjadi undang-undang pada tahun 1958 yang diberi nama

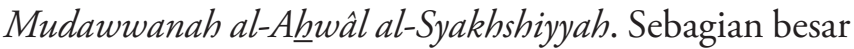
aturan-aturan tersebut berdasarkan Mazhab Mâlikî dan beberapa bagian lainnya sama dengan hukum keluarga Tunisia, Majallah al-Ahwâl al-Syakhshiyyah. Hal ini disebabkan kesamaan mazhab yang dianut kedua negara ini, yakni Mazhab Mâlikî.

Sementara itu, Yordania yang merupakan salah satu daribekaskerajaan Ottoman beradadalam pemerintahan tidak langsung dari Pemerintah Inggris. Sistem hukum kerajaan Ottoman tetap dipertahankan. Pada 1927, beberapa hukum Ottoman, termasuk di dalamnya The Ottoman law of Family Right 1917, ditetapkan kembali dengan beberapa perubahan. ${ }^{79}$ Kerajaan Yordania menjadi negara merdeka secara penuh pada tanggal 1 Februari 1947 dengan Islam sebagai agama negara. ${ }^{80}$ Konsep dasar sistem hukum Yordania berasal

\footnotetext{
${ }^{78}$ Tahir Mahmood, Family Law Reform in The Muslim World, h. 118.

${ }^{79}$ Tahir Mahmood, Family Law Reform in The Muslim World, h. 119.

${ }^{80}$ The constitution of Jordan, article 2.
} 
dari kerajaan Ottoman dengan mengalami beberapa perubahan untuk keperluan penyesuaian dengan kebutuhan masyarakat waktu itu.

Undang-undang Keluarga Yordania 1951 merupakan seri pertama dari proses kodifikasi hukum keluarga Islam yang dikeluarkan pada 1950-an oleh badan legislatif nasional negara Arab yang baru merdeka. Konstitusi yang baru diadopsi pada 1952 dengan mempertahankan agama dan hak-hak umum sebagai dasar yurisdiksi dalam persoalan-persoalan yang berhubungan dengan status personal. Meskipun pada awalnya Yordania membentuk satu regulasi hukum keluarga sendiri, namun pada perkembangan selanjutnya pemerintah kembali mengadopsi hukum keluarga yang didasarkan pada sebagian besar hukum keluarga kerajaan Ottoman.

Undang-undang status personal Yordania digantikan dengan Undang-Undang Hak Keluarga Yordania tahun 1951. Undang-undang ini menyajikan sebuah regulasi yang lebih komprehensif dengan mempertahankan konsep fikih klasik Hanafî dalam ketiadaan referensi yang spesifik dalam bentuk teks. Tarik ulur usaha pembentukan peraturan yang mengatur masalah hukum keluarga di Yordania pada akhirnya mengarah pada kodifikasi peraturan yang didasarkan pada fikih klasik Mazhab ㅂanafî.

Sementara itu, proses reformasi negara Pakistan, dalam rangka penyusunan hukum keluarga Muslim yang baru, dimulai sejak 1955. Pemerintah Pakistan membentuk suatu komisi yang terdiri atas tujuh anggota yang semuanya merupakan ahli agama. Komisi ini bertugas mensurvai masalah-masalah yang berkaitan dengan perkawinan dan hukum keluarga dengan tujuan merekomendasikan posisi kaum perempuan di masyarakat sesuai dengan dasar-dasar agama Islam. ${ }^{81}$ Pada 1956, pemerintah mengumumkan bahwa di masa mendatang tidak ada hukum yang diberlakukan bertentangan dengan syariat. Undang-undang yang sudah berlaku akan ditinjau ulang dan direvisi sesuai dengan perintah tersebut. ${ }^{82}$

Pada 1961, berdasarkan laporan dan rekomendasi Komisi Tujuh tersebut, Muslim Family Laws Ordonance (MFLO) 1961 secara resmi diumumkan. ${ }^{83}$ MFLO 1961 ini berisi aturan tentang pencatatan perkawinan, poligami, perceraian, nafkah (biaya hidup), mahar, hak waris bagi cucu, dan batas usia perkawinan. Untuk

\footnotetext{
${ }^{81}$ The constitution of Jordan, article 2.

${ }^{82}$ The constitution of Jordan, article 2.

${ }^{83}$ Tahir Mahmood, Family Law Reform in The Muslim World, h. 248.
}

memutuskan sengketa perkawinan dan keluarga Muslim, dibentuk pengadilan keluarga (family court) pada tahun $1964 .{ }^{84}$

\section{Analisis Perbandingan}

Dari ketentuan beberapa negara tersebut, maka dapat dilakukan analisis, yaitu: (1) Analisis perbandingan horizontal, yaitu memberikan perbandingan dari sisi persamaan dan perbedaan antara negara tersebut dalam mengatur ketentuan tentang mahar. (2) Analisis perbandingan vertikal, yaitu membandingkan undang-undang yang berlaku di negara tersebut dengan ketentuan yang ada dalam kitab fikih, baik berdasarkan mazhab yang dianut oleh negara tersebut atau berdasarkan mazhab lainnya.

Pada tataran analisis perbandingan horizontal, terlihat bahwa lima negara tersebut yaitu Maroko, Yordania, Syria, Pakistan, dan Indonesia memiliki kesamaan dalam menyatakan status kepemilikan mahar, yaitu merupakan milik mutlak isteri. Meskipun Yordania menambahkan ketentuan bahwa kepemilikan mahar dapat diambil oleh ayah atau kakek, namun dengan syarat adanya kerelaan dari mempelai lakilaki untuk membayar. Selain itu, baik secara eksplisit maupun implisit, pembayaran mahar bukan dengan tujuan untuk membeli seorang perempuan dari walinya sebagaimana yang telah dipraktekkan pada masa Arab pra-Islam.

Persamaan lainnya adalah dalam memberikan rincian tentang ketentuan mahar dan bentuknya, yaitu memberikan aturan yang lebih rinci melalui ijtihad, terutama dalam masalah mahar yang masih terhutang. Beberapa hal yang dapat dicatat adalah mengenai pembayaran mahar yang masih terhutang apabila terjadi perceraian, sebab terjadinya perceraian tersebut, dan inisiatif perceraian itu, apakah datang dari pihak suami atau isteri, serta perselisihan suami isteri tentang apakah mahar sudah dibayar atau belum dan jumlah mahar yang telah diperjanjikan. Peraturan secara rinci tentang hal ini oleh seluruh negara Muslim tersebut sangat diperlukan oleh hakim sebagai pedoman apabila permasalahan tersebut sampai ke pengadilan.

Perbedaan yang terlihat dari beberapa ketentuan yang berlaku di beberapa negara tersebut adalah dalam menentukan jumlah mahar. Negara Pakistan mencantumkan dalam aturan yang berlaku bahwa maksimal mahar adalah 5000 rupee. Bahkan sampai pada kado pernikahan dan biaya pernikahan juga diberikan

${ }^{84}$ Tahir Mahmood, Family Law Reform in The Muslim World, h. 119. 
pembatasan maksimal. Selain itu, adanya keharusan bagi wali untuk melaporkan kepada pegawai pencatat pernikahan tentang biaya pernikahan dalam waktu 15 hari setelah pelaksanaan akad nikah. Sanksi pidana akan diberikan kepada para pihak yang melanggar ketentuan dalam undang-undang tersebut. Dalam hal ini Pakistan merupakan negara yang lebih berani memberikan sanksi pidana dalam masalah mahar.

Negara Maroko, Yordania, dan Syria memiliki ketentuan adanya perbedaan antara mahar mitsil (mahar yang sesuai dengan status sosial isteri) dan mahar khusus. Sedangkan dalam Kompilasi Hukum Islam di Indonesia lebih pada jumlah pemberian mahar yang sesuai dengan kesepakatan antara kedua belah pihak. Negara selain Indonesia lebih banyak mengatur pada masalah mahar yang terhutang, karena jumlah mahar di negaranegara tersebut cukup besar. Sedangkan dalam aturan yang berlaku di Indonesia, tidak banyak mengatur hal tersebut karena mahar dalam tradisi perkawinan lebih pada mahar yang dibayar secara tunai, walaupun tidak menutup kemungkinan untuk berhutang.

Berdasarkan analisis perbandingan vertikal, negara Maroko, yang dikenal sebagai penganut Mazhab Mâlikî, sebenarnya tetap mempertahankan konsep mahar sebagaimana yang terdapat dalam Mazhab Mâlikî, seperti mahar bukanlah rukun nikah. Hanya saja undang-undang negara tersebut menyajikan sebuah regulasi yang lebih rinci dan komprehensif, karena masalah mahar, apalagi mahar yang terhutang, tidak menutup kemungkinan akan terjadinya sengketa di kemudian hari dan harus diselesaikan oleh hakim.

Negara Yordania dan Syria, 2 negara yang menganut Mazhab Hanafî, juga tidak jauh berbeda dalam semangat pembaharuan hukum keluarga, khususnya dalam masalah mahar dengan Maroko. Masalah mahar yang terhutang tidak akan dapat dielakkan untuk dibayar oleh suami meskipun telah terjadi perceraian. Bahkan hutang mahar merupakan suatu yang prioritas dan sama dengan status pembayaran nafkah.

Pakistan adalah negara dimana kaum Suni bermazhab Hanafî dan kaum Syiahnya menganut Mazhab Itsnâ 'Asy'ariyah. Dalam peraturan yang berlaku, dengan memberikan ancaman pidana bagi siapa saja yang menerima mahar melebihi batas maksimal, hal itu merupakan suatu bentuk pembaharuan yang sudah beranjak jauh dari ketentuan yang ada dalam kitab fikih klasik. Hal itu dimungkinkan karena dilatarbelakangi oleh praktek dimana pihak wali lebih mendominasi dalam menetapkan jumlah mahar, atau pemberian yang seolah-olah statusnya sama dengan mahar, dan juga dalam jumlah yang besar, sehingga hal itu memberatkan pihak yang akan melakukan akad nikah. Jadi aturan itu dibuat untuk mengembalikan konsep dasar Islam yang tidak mempersulit masalah pemberian mahar

Kompilasi Hukum Islam di Indonesia yang mengatur beberapa ketentuan tentang mahar lebih menekankan pada pemberian mahar berdasarkan asas kesederhanaan dan kemudahan, sehingga diharapkan mahar itu diberikan dalam bentuk tunai. Sekalipun harus berhutang, namun harus atas persetujuan isteri. Pengadilan Agama mendapat kewenangan untuk menyelesaikan sengketa tentang jumlah dan jenis mahar.

\section{Penutup}

Dari uraian di atas dapat diambil kesimpulan mengenai ketentuan mahar di negara Maroko, Yordania, Syria, Pakistan, dan Indonesia. Seluruh negara tersebut memberikan aturan yang jelas, tegas, dan rinci dalam masalah mahar, terutama dalam masalah terjadinya perceraian dan mahar masih dalam keadaan terhutang. Selain itu, semangat untuk menghindarkan besarnya jumlah mahar juga tergambar dalam ketentuan yang berlaku. Bahkan Pakistan dengan tegas melakukan pembatasan jumlah maksimal mahar sekaligus memberikan sanksi bagi pihak wali yang melanggar ketentuan tersebut. []

\section{Pustaka Acuan}

Bukhârî, al-, Imâm, Shahîh al-Bukhârî,, Beirut: Dâr alFikr, 1978.

El Alami, Dawoud dan Doreen Hinchcliffe, Islamic Marriage and Divorce Laws, London: Kluwer Law International, 1996.

Ibn Anas, Mâlik, Al-Muwaththa', di-tash $\underline{h} \underline{\underline{h}}$ oleh Muhammad Fu'âd 'Abd al-Bâqî, Beirut: Dâr al-Fikr, 1985.

Ibn Qudâmah, Muwaffaq al-Dîn Abû Muhammad 'Abd Allâh ibn Ahmad , Al-Mughnî wa al-Syarh al-Kabîr, Beirut: Dâr al-Fikr, 1984 M.

Mahmood, Tahir, Family Law Reform in The Muslim World, Bombay: N.M Tripathi PVT, 1970.

Nasution, Khoiruddin, Islam tentang Relasi Suami dan Isteri (Hukum Perkawinan 1 \& 2), Jakarta: ACAdeMIA\&TAZZAFA, 2004.

Nuruddin, Amiur dan Azhari Akmal Tarigan, Hukum Perdata Islam di Indonesia,Jakarta: Raja Grafindo Persada, 2004.

Sâbiq, Sayyid, Fiqh al-Sunnah, Beirut: Dâr al-Kitâb al'Arabî, 1392 H/1973M.

Sarakhsî, al-, Syams al-Dîn, Al-Mabsûth, Beirut: Dâr alMa’rifah, 1989 M. 